\title{
Diversity within the Microcystin Biosynthetic Gene Clusters among the Genus Microcystis
}

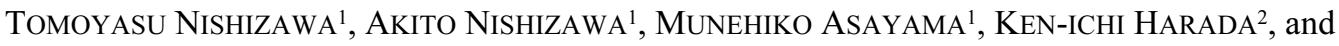 \\ MAKOTO SHIRAI ${ }^{1 *}$ \\ ${ }^{1}$ Laboratory of Molecular Genetics, College of Agriculture, Ibaraki University, Ami, Ibaraki 300-0393, Japan \\ ${ }^{2}$ Laboratory of Environmental Sciences, Faculty of Pharmacy, Meijo University, Tempaku, Nagoya 468-8503, \\ Japan
}

(Received July 25, 2007-Accepted September 11, 2007)

The principle organization of microcystin biosynthesis $(m c y)$ gene clusters is characterized in three genera among the microcystin-producing cyanobacteria. To examine the conservation of the $m c y$ gene clusters among the genus Microcystis, internal non-coding regions of the cluster in 21 strains including M. aeruginosa, M. viridis, and $M$. wesenbergii, were amplified by PCR using specific primer sets and sequenced. PCR-based analysis revealed a completely conserved organization of the bidirectional cluster structure, $m c y A B C$ and $m c y D E F G H I J$, among all toxic and some microcystin-negative strains. Furthermore, all $m c y$ gene clusters were flanked by a gene with homology to dnaN adjacent to $m c y J$ and by umal with no-homology to any known genes at the 3'-end of $m c y C$. Transposase homolog genes were observed in a non-coding region between $d n a N$ and $m c y J$ in three microcystin-producing Microcystis strains. Sequence analysis of a region adjacent to umal in mcy-negative strains revealed two types of gene constitution, dnaN-umal and the hypothetical protein gene-umal. PCR-based analyses can be used to assess the identification of microcystin-producer strains in Microcystis spp.

Key words: Cyanobacteria, Microcystis, Microcystin biosynthetic gene, Non-ribosomal peptide synthetase, Polyketide synthase

Noxious cyanobacterial waterblooms are occurring worldwide in eutrophic lakes, ponds, and dams. Members of the genus Microcystis, a major cause of freshwater blooms, can be toxic. Microcystins, a family of cyclic heptapeptide toxins that are produced by most members of this genus, cause acute hepatotoxicity in agricultural livestock ${ }^{1,38)}$. The toxicity of microcystins is due to the inhibition of protein phosphatase 1 and $2 \mathrm{~A}^{8,16)}$. The increasing occurrence of Microcystis blooms in sources of human drinking water is very problematic ${ }^{5)}$.

\footnotetext{
* Corresponding author. E-mail address: shirai@mx.ibaraki.ac.jp; Tel.: +81-29-888-8652; Fax: +81-29-888-8653.

Abbreviations: Adda, 3-amino-9-methoxy-2,6,8-trimethyl-10-phenyl-deca-4,6-dienoic acid; D-MeAsp, D-erythro- $\beta$-methyl-aspartic acid; Mdha, $N$-methyldehydroalanine; ITS, internal transcribed spacer sequence; MCYST, microcystin; NJ, neighbor-joining; NRPS, non-ribosomal peptide synthetase; PKS, polyketide synthase.
}

Microcystins share a common structure, cyclo (Adda-DGlu-Mdha-D-Ala-L-X-D-MeAsp-L-Z-), in which X and Z are variable L-amino acids, Adda is 3-amino-9-methoxy2,6,8-trimethyl-10-phenyldeca-4,6-dienoic acid, D-MeAsp is D-erythro- $\beta$-iso-aspartic acid, and Mdha is $N$-methyldehydroalanine. Peptides containing non-proteinogenic amino acids are synthesized by non-ribosomal peptide synthetases (NRPSs), which are a family of multifunctional enzymes ${ }^{9)}$. NRPSs are composed of modules, each of which is responsible for the activation of an amino acid, thiolation, and condensation $^{9}$. Notably, epimerization and methylation occurred the NRPS module in order to modify the amino acid. Recently, microcystin synthetase genes have been cloned and sequenced from the microcystin-LR type producer Microcystis aeruginosa ${ }^{17,18,35)}$, which produces heptapeptide micropeptin/cyanopeptolin as well ${ }^{4,10}$. The $m c y$ $A B C$ cluster has the opposite orientation to the $m c y D E F G$ cluster $^{18,35)}$. Additionally, monofunctional proteins for 
(A)
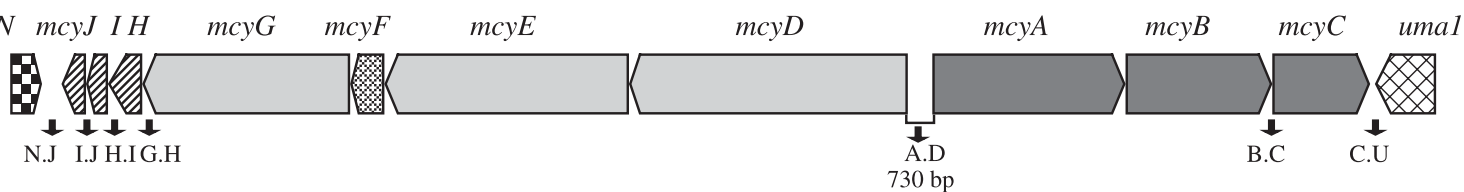

(B)

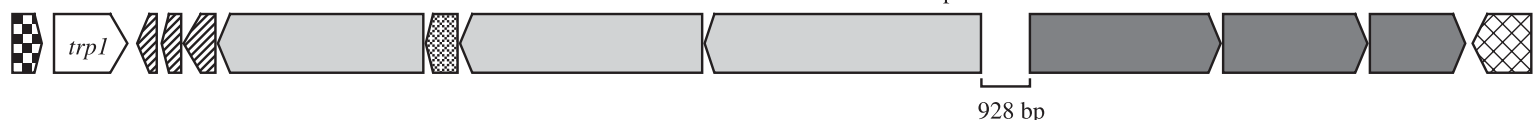

(C)



(D)

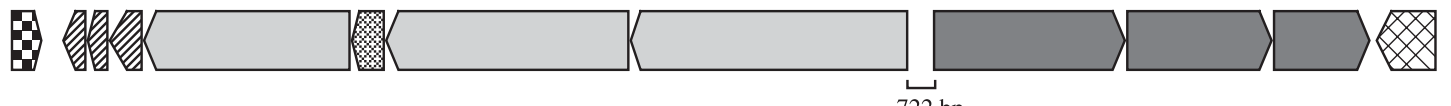

(E)
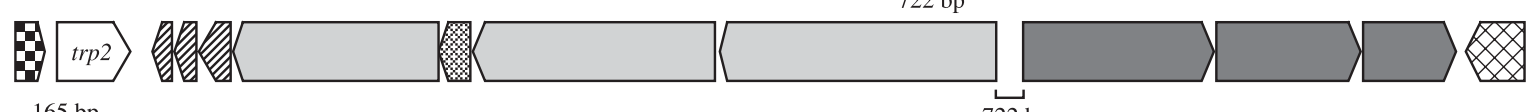

(F)
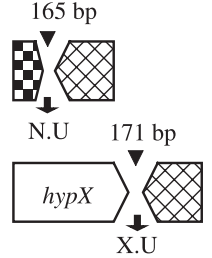

(G)

(H)

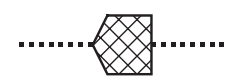

Fig. 1. Five types of the $m c y$ gene organization between $d n a N$ and $u m a l$ and three types of $m c y$-negative gene organization downstream of the umal gene in the genus Microcystis. Primer locations and PCR fragments are indicated at the bottom of the gene structure. dnaN, DNA polymerase III $\beta$ subunit; umal, hypothetical protein; $m c y A-m c y C$, NRPSs cluster; $m c y D-m c y G$, polyketide synthase (PKS), PKS-NRPS, racemase and NRPS-PKS cluster; $m c y H$, ABC transporter ATP-binding protein; $m c y I$, dehydrogenase; $m c y J, O$-methyltransferase; trpl, putative transposase of cyanobacteria; trp2, Tn5-like transposase of bacteriophage WO; hypX, hypothetical $29.6 \mathrm{kDa}$ lipoprotein of $E$. coli. The number of base pairs indicates the length of a non-coding region.

microcystin biosynthesis, including McyF involved in epimerization ${ }^{19,31)}$, the $\mathrm{ABC}$ transporter $\mathrm{McyH}^{22)}$, the hydroxy-acid dehydrogenase $\mathrm{McyI}^{23)}$, and McyJ involved in $O$-methylation that was identified in the filamentous cyanobacterium Planktothrix ${ }^{2}$, were located within the mcy gene cluster. The umal (our previous named orf2) gene, which shows a high degree of similarity to a hypothetical protein (S110471) of Synechocystis sp. PCC 6803, is located downstream of $m c y C$ in $M$. aeruginosa K-139 (Fig. 1A) ${ }^{17)}$. The $m c y$ gene cluster set was conserved in a filamentous heterocystous Anabaena strain ${ }^{25)}$ and Planktothrix strain as well ${ }^{2}$. Interestingly, disruption of $m c y A, m c y B, m c y E$, and $m c y F$ in Microcystis viridis S-70, which produces three kinds of microcystins, demonstrated that one set of the mcy gene clusters is responsible for the production of microcystin-LR, $-R R$, and -YR ${ }^{18,19)}$. Furthermore, genomic Southern hybridization using $m c y$ probes from $M$. aeruginosa K-139 showed the presence of the $m c y$ gene in the microcystin non-producing strain $M$. aeruginosa $\mathrm{K}-81^{17,18)}$.

For the identification of toxic strians among the genus
Microcystis, phylogenetic analyses as a tool for molecular ecological studies were performed based on $16 \mathrm{~S}$ rDNA or the $16 \mathrm{~S}$ to $23 \mathrm{~S}$ internal transcribed spacer sequence (16S23S ITS), which can be used to differentiate more closely related strains ${ }^{7,14,21)}$. Recently, based on PCR amplification using the $m c y$ genes, several groups reported that the presence of the $m c y$ gene cluster was correlated to a certain subspecies level allowing one to distinguish the productive capacity of microcystins ${ }^{36,39)}$. Moreover, according to phylogenetic analyses using the PCR-amplified $m c y$ genes, gene recombination was suggested by the genetic variation of the $m c y$ genes between different strains of Microcystis spp. ${ }^{13,33)}$. Alternatively, to solve the entire evolutionary history of microcystins, a phylogenetic analysis of the coevolution of 16S rDNA and a housekeeping gene, $r p o C$, was performed. The presence of the mcy gene cluster in the last common ancestor of a large number of cyanobacteria was proposed $^{24)}$. However, ecological investigations have yet to describe the $m c y$ gene organization in relation to toxicity.

In the present study, we revealed the highly conserved 
$m c y$ gene organization in three domestic morphospecies, $M$. aeruginosa, M. viridis, and M. wesenbergii. Additionally, we discuss the connection between the conservation of $m c y$ gene clusters and evolutionary incidents in the genus Microcystis.

\section{Materials and Methods}

\section{Cyanobacterial strains and culture conditions}

All cyanobacterial strains with the designation NIES were obtained from the National Institute for Environmental Studies (NIES: Tsukuba, Japan). Microcystis strains MB and MG were provided by Prof. Kaplan, A. culture collection (The Hebrew University of Jerusalem, Israel) ${ }^{37)}$. The remaining strains were from a culture collection of the authors (Shirai, M., Ibaraki University, Japan) ${ }^{3,20,26,29,30)}$ (Table 1). Strains were grown in $\mathrm{CB}$ or MA medium at $30^{\circ} \mathrm{C}$ under continuous illumination with fluorescent (cool white) light at $35 \mu \mathrm{mol} \mathrm{m} \mathrm{m}^{-2} \mathrm{~s}^{-130,38)}$.

\section{DNA extraction and manipulation}

Total cyanobacterial DNA was isolated from cells grown to the late logarithmic phase using a previously described procedure ${ }^{17}$. Escherichia coli DH5 $\alpha$ MCR (Cosmo Bio., Tokyo, Japan) was used as a host for recombinant plasmids and grown at $37^{\circ} \mathrm{C}$ in $2 \times \mathrm{YT}$ broth or $2 \times \mathrm{YT}$ agar broth. Antibiotics were added as necessary at the following final concentrations: ampicillin $75 \mu \mathrm{g} / \mathrm{ml}$. pUC119 (Toyobo, Tokyo, Japan) and pMOSBlue T-vector (GE-Healthcare UK Ltd., Buckinghamshire, England) were used for cloning. DNA manipulations were performed as described previously ${ }^{27)}$.

\section{Southern hybridization analysis of the umal gene}

Digested cyanobacterial DNA was separated on $0.8 \%$ agarose gels and then transferred to Hybond-N or NX membranes (GE-Healthcare UK Ltd.) as described previously ${ }^{17)}$.

Table 1. Microcystis strains used in this study

\begin{tabular}{|c|c|c|c|c|c|}
\hline Strain & $\begin{array}{l}\text { Date; } \\
\text { year/month }\end{array}$ & Origin, Isolation site & Reference & $\begin{array}{l}\text { Accession } \\
\text { number of } \\
\text { 16S-23S ITS }\end{array}$ & Microcystin \\
\hline \multicolumn{6}{|l|}{ Microcystis spp. } \\
\hline M. aeruginosa NIES44 & 1974/Aug. & Lake Kasumigaura, Ibaraki & NIES collection & AB254437 & no \\
\hline M. aeruginosa NIES89 & 1981/Jun. & Lake Kawaguchi, Yamanashi & NIES collection & AB254439 & MCYST \\
\hline M. aeruginosa NIES90 & 1981/Jun. & Lake Kawaguchi, Yamanashi & NIES collection & AB254440 & MCYST-LR, -RR \\
\hline M. aeruginosa NIES 87 & 1982/Sep. & Lake Kasumigaura, Ibaraki & NIES collection & AB254438 & no \\
\hline M. aeruginosa NIES98 & 1982/Sep. & Lake Kasumigaura, Ibaraki & NIES collection & AB254441 & no \\
\hline M. aeruginosa NIES298 & 1982/Sep. & Lake Kasumigaura, Ibaraki & NIES collection & AB254442 & MCYST-LR, [D-Asp $\left.{ }^{3}\right]$ MCYST-LR \\
\hline M. aeruginosa K-81 & 1985/Sep. & Lake Kasumigaura, Ibaraki & $(20,26)$ & AB254411 & no \\
\hline M. aeruginosa K-139 & 1985/Sep. & Lake Kasumigaura, Ibaraki & $(3,26)$ & AB254412 & $\begin{array}{l}{\left[\mathrm{Dha}^{7}\right] \mathrm{MCYST}-\mathrm{LR},\left[\mathrm{D}-\mathrm{Asp}^{3}, \mathrm{Dha}^{7}\right]} \\
\text { MCYST-LR }\end{array}$ \\
\hline M. aeruginosa B-19 & 1987/Sep. & Lake Kasumigaura, Ibaraki & $(26,29)$ & AB254408 & no \\
\hline M. aeruginosa B-35 & 1987/Sep. & Lake Kasumigaura, Ibaraki & $(30)$ & AB254409 & MCYST-LR, -RR, -YR \\
\hline M. aeruginosa $\mathrm{B}-47$ & 1987/Sep. & Lake Kasumigaura, Ibaraki & $(26,29)$ & AB254410 & $\begin{array}{l}{\left[\mathrm{Dha}^{7}\right] \mathrm{MCYST}-\mathrm{LR},\left[\mathrm{D}-\mathrm{Asp}^{3}, \mathrm{Dha}^{7}\right]} \\
\text { MCYST-LR }\end{array}$ \\
\hline M. aeruginosa S-77 & 1988/Jul. & Lake Kasumigaura, Ibaraki & $(26,30)$ & AB254413 & MCYST-LR, -RR, -YR \\
\hline M. aeruginosa S-78 & 1988/Jul. & Lake Kasumigaura, Ibaraki & This study & AB254414 & no \\
\hline M. aeruginosa $\mathrm{TC}$ & 1989/Sep. & Lake Kasumigaura, Ibaraki & This study & AB254415 & no \\
\hline M. viridis NIES103 & 1978/Dec. & Lake Kasumigaura, Ibaraki & NIES collection & AB254444 & MCYST \\
\hline M. viridis NIES102 & 1982/Sep. & Lake Kasumigaura, Ibaraki & NIES collection & AB254443 & MCYST-LR, -RR, -YR \\
\hline M. viridis $\mathrm{S}-70$ & 1988/Jul. & Lake Kasumigaura, Ibaraki & $(26,30)$ & AB254418 & MCYST-LR, -RR, -YR \\
\hline M. wesenbergii NIES107 & 1981/Jun. & Lake Kawaguchi, Yamanashi & NIES collection & AB254445 & MCYST \\
\hline M. wesenbergii NIES112 & 1982/Oct. & Lake Suwa, Nagano & NIES collection & AB015393 & no \\
\hline Microcystis $\mathrm{MB}$ & 2000 & Israel & (37) & AB254416 & no \\
\hline Microcystis MG & 2000 & Israel & $(37)$ & AB254417 & MCYST-RR, MCYST \\
\hline
\end{tabular}

MCYST, microcystin; [Dha $]$ MCYST-LR, 7-desmethylmicrocystin-LR; [D-Asp ${ }^{3}$, Dha ${ }^{7}$ MCYST-LR, 3,7-didesmethylmicrocystin-LR; [DAsp $^{3}$ ]MCYST-LR, 3-desmethylmicrocystin-LR; no, non-microcystin-producing Microcystis. 
DNA fragments, a 0.69-kb SmaI fragment containing part of the umal gene from pMCX2 as a probe ${ }^{17)}$, were labeled using an ECL random prime labeling Kit (GE-Healthcare UK Ltd.). Southern hybridization and detection were performed as recommended by the manufacturer.

Cloning of dnaN-umal and hypX-umal from non-microcystin-producing M. aeruginosa

To characterize the umal gene from a non-microcystinproducing $M$. aeruginosa strain, shotgun clonings were performed using a $0.69-\mathrm{kb}$ SmaI fragment containing part of the umal gene from pMCX2 as a probe ${ }^{17)}$. XbaI-digested total $M$. aeruginosa B-19 DNA was shotgun cloned into the $X b a \mathrm{I}$ site of the vector pUC119. The resultant recombinant pBJK3, which contained a 2.5-kb XbaI fragment, was iso- lated and sequenced. Using the umal probe, $X b a \mathrm{I}$-digested total chromosomal DNA of strain NIES98 was shotgun cloned into the XbaI site of pUC119. pNKH2, which contained a 1.9-kb XbaI fragment, was cloned and sequenced. Moreover, to obtain the rest of umal in strain NIES98, the ClaI-digested total DNA was shotgun cloned into the ClaI site of pBluescript II $\mathrm{KS}(+)$ (Toyobo), using a $0.63-\mathrm{kb}$ $X b a \mathrm{I}-H i n \mathrm{dIII}$ fragment from the downstream umal region of the insert of pNKH2 as a probe. Recombinant pNKI10 containing a 2.6-kb ClaI fragment was inserted and sequenced.

\section{Polymerase Chain Reaction (PCR) amplification}

To amplify between the dnaN and umal genes following the microcystin biosynthetase genes, primers sets were

Table 2. Specific PCR primers for the $m c y$ gene organization

\begin{tabular}{|c|c|c|c|c|}
\hline \multicolumn{2}{|c|}{$\begin{array}{l}\text { Amplified region (Annealing temp.) } \\
\text { Name of primer }\end{array}$} & \multirow[t]{2}{*}{$\operatorname{Tm}\left({ }^{\circ} \mathrm{C}\right)$} & \multicolumn{2}{|c|}{ Oligonucleotide primer sequence, from 5'-3' (length, mer) } \\
\hline$d n a N-m c y J$ & $\left(56^{\circ} \mathrm{C}\right)$ & & & \\
\hline 3'-dnaN & & 55.0 & AATGCTAGATACCCAACCGG & $(19)$ \\
\hline 3'-mcyJ & & 55.0 & AACCCAGGACTCGAAGC & $(17)$ \\
\hline$m c y I-J$ & $\left(56^{\circ} \mathrm{C}\right)$ & & & \\
\hline 5'-mcyJ & & 53.0 & AAAAGGTGATCTCCGGC & $(17)$ \\
\hline 3'-mcyI & & 57.0 & GCAAAGCGGAGACAGTAGG & $(19)$ \\
\hline dnaN-mcyI & $\left(56^{\circ} \mathrm{C}\right)$ & & & \\
\hline $3^{\prime}-\mathrm{dnaN}$ & & 55.0 & & \\
\hline 3'-mcyI & & 57.0 & & \\
\hline$m c y H-I$ & $\left(55^{\circ} \mathrm{C}\right)$ & & & \\
\hline 5'-mcyI & & 53.0 & ACGCACAAATACGCCAG & $(17)$ \\
\hline 3'-mcyH & & 55.0 & TAGTAACCCATCCCCGC & $(17)$ \\
\hline$m c y G-H$ & $\left(55^{\circ} \mathrm{C}\right)$ & & & \\
\hline 5'-mcyH & & 55.0 & GAGGCAACCAGTCCAAC & $(17)$ \\
\hline 3'-mcyG & & 55.0 & TCGGAGAACGTCGGGAA & $(17)$ \\
\hline$m c y A-D$ & $\left(58^{\circ} \mathrm{C}\right)$ & & & \\
\hline NSZW1 & & 58.0 & CTTGAAGTTGCCGAATTTGG & $(20)$ \\
\hline PKM1-a & & 62.0 & GGATTGATTGGTCGTTTTCGG & $(21)$ \\
\hline$m c y B-C$ & $\left(56^{\circ} \mathrm{C}\right)$ & & & \\
\hline FB & & 63.8 & GGATCCACTCTGAAGGCGATGCG & (23) \\
\hline $\mathrm{BB}$ & & 63.8 & GGATCCTCTAGGGTAAGAGGGGGT & $(24)$ \\
\hline mcyC-umal & $\left(56^{\circ} \mathrm{C}\right)$ & & & \\
\hline 3'-mcyC & & 57.0 & AGAGGAGGACGTGAGGC & $(17)$ \\
\hline 3'-uma1 & & 57.0 & GTCCTCTGGGGTAGCTG & $(17)$ \\
\hline dnaN-umal & $\left(56^{\circ} \mathrm{C}\right)$ & & & \\
\hline $3^{\prime}-$ dnaN & & 55.0 & & \\
\hline 3'-uma1 & & 57.0 & & \\
\hline hypX-umal & $\left(57^{\circ} \mathrm{C}\right)$ & & & \\
\hline 3'-hypX & & 57.0 & ATTGGCCAGAGGTCGCC & $(17)$ \\
\hline 3'-uma1 & & 57.0 & & \\
\hline
\end{tabular}


designed (Table 2). The reactions were performed in a MiniCycler (MJ Research, Watertown, USA). For amplifications, Gene Taq (Nippon Gene, Toyama, Japan) and TaKaRa LA Taq ${ }^{\mathrm{TM}}$ (Takara Bio, Otsu, Japan) were used for short PCR and long PCR, respectively. The reaction was performed under the following conditions; dnaN-mcyJ, mcyI-J, dnaN-mcyI, and danN-uma1, $1 \mathrm{~min}$ at $95^{\circ} \mathrm{C}$, then 25 cycles of $95^{\circ} \mathrm{C}(30 \mathrm{~s}), 56^{\circ} \mathrm{C}(15 \mathrm{~s})$, and $70^{\circ} \mathrm{C}(2 \mathrm{~min})$, and $3 \mathrm{~min}$ at $70^{\circ} \mathrm{C}$; mcyC-uma1, mcyG-H, and mcyH-I, 1 min at $95^{\circ} \mathrm{C}$, then 25 cycles of $95^{\circ} \mathrm{C}(30 \mathrm{~s}), 55^{\circ} \mathrm{C}(30 \mathrm{~s})$, and $70^{\circ} \mathrm{C}$ (1.5 $\mathrm{min}$ ), and $3 \mathrm{~min}$ at $70^{\circ} \mathrm{C}$; mcyA-D non-coding region, 1 min at $95^{\circ} \mathrm{C}$, then 25 cycles of $95^{\circ} \mathrm{C}(30 \mathrm{~s}), 58^{\circ} \mathrm{C}(30 \mathrm{~s})$ and $72^{\circ} \mathrm{C}(1.5 \mathrm{~min})$, and $3 \mathrm{~min}$ at $72^{\circ} \mathrm{C}$; hypX-uma $1,1 \mathrm{~min}$ at $95^{\circ} \mathrm{C}$, then 25 cycles of $95^{\circ} \mathrm{C}(30 \mathrm{~s}), 57^{\circ} \mathrm{C}(30 \mathrm{~s})$, and $72^{\circ} \mathrm{C}$ ( $2 \mathrm{~min}$ ), and $3 \mathrm{~min}$ at $72^{\circ} \mathrm{C}$. The mcyB-C and core regions were amplified as described previously ${ }^{17}$. PCR products were resolved on $2.0-1.5 \%$ agarose gels in Tris-borateEDTA buffer.

\section{PCR amplification of the 16S-23S ITS region}

Primers for amplification of the DNA region including 16S-23S ITS were designed according to Otsuka et al. ${ }^{21)}$ with some modifications of PCR conditions. First, to amplify the $16 \mathrm{~S}-23 \mathrm{~S}$ regions of the Microcystis spp., MSR$\mathrm{S} 2 \mathrm{~F}$ and $242 \mathrm{r}$ derived from conserved E. coli $16 \mathrm{~S}-23 \mathrm{~S}$ rDNA were used as forward and reverse primers. The reaction was carried out under the following conditions; $1 \mathrm{~min}$ at $95^{\circ} \mathrm{C}$, then 25 cycles of $95^{\circ} \mathrm{C}(30 \mathrm{~s}), 50^{\circ} \mathrm{C}(30 \mathrm{~s})$, and $70^{\circ} \mathrm{C}(1.5 \mathrm{~min})$, and $3 \mathrm{~min}$ at $72^{\circ} \mathrm{C}$. An amplified band of approximately $1.4 \mathrm{~kb}$ was prepared. Then the primers $1505 \mathrm{f}$ and $115 \mathrm{r}$ were used for sequencing and nested PCR was performed with the prepared fragment. The nested PCR profile was: $1 \mathrm{~min}$ at $95^{\circ} \mathrm{C}$, then 25 cycles of $95^{\circ} \mathrm{C}(30 \mathrm{~s}), 56^{\circ} \mathrm{C}$ $(30 \mathrm{~s})$, and $70^{\circ} \mathrm{C}(1.5 \mathrm{~min})$, and $3 \mathrm{~min}$ at $72^{\circ} \mathrm{C}$.

\section{Sequencing}

Dideoxy chain termination using an Applied Biosystems Automated Sequencer model 310 (PE Biosystems, Foster, USA) was used to determine the nucleotide sequences of double-stranded template DNA fragments of the PCR products and the cloned plasmid derived from deletion clones generated using Exonuclease III and Mung Bean Nuclease ${ }^{17)}$.

\section{Computer analysis of DNA sequences}

The DNA sequences were assembled and analyzed using GENETYX-MAC from Genetyx Co. (Tokyo, Japan). Phylogenetic analyses were carried out using the multiplesequence alignment tool from CLUSTAL W ${ }^{34}$.

\section{Nucleotide sequence accession numbers}

The nucleotide sequences in this report have been submitted to DDBJ under the following accession numbers: AB019578 and AB032549 (microcystin biosynthetic gene cluster from M. aeruginosa K-139), AB254433 (dnaN-trp1mcyJ from M. aeruginosa B-47), AB254434 (dnaN-umal from M. aeruginosa B-19), AB254435 (hypX-umal from M. aeruginosa NIES98), AB254436 (dnaN-trp2-mcyJ from M. viridis NIE102).

\section{Results}

Identification of the region adjacent to the mcy cluster

To examine the existence of umal within the genus Microcystis including nine non-microcystin-producing strains (Table 1), a genomic Southern hybridization analysis using the umal probe was carried out. Hybridization signals were observed with the DNA digested from all Microcystis strains examined, suggesting that umal is highly conserved in Microcystis strains (data not shown). In our previous study, no NRPS/PKS of the mcyABCDEFG gene was detected by genomic Southern hybridization in $M$. aerguinosa B-1917,18). To reveal whether M. aeruginosa B-19 possesses a part of mcy near a downstream region of umal, shotgun cloning using the umal probe was performed. An open reading frame, which shows a high level of similarity to a DNA polymerase III $\beta$ subunit (dnaN) of Synechocystis sp. PCC 6803, was found with the opposite orientation to umal (Fig. 1F). Actually, using a specific primer set for the dnaN gene, PCR-amplified products were obtained from the nine non-microcystin-producing strains.

Conservation of the mcy gene cluster among the genus Microcystis

To clarify the arrangement of the $m c y$ gene cluster among the genus Microcystis, PCR amplification and genomic Southern hybridization using $m c y$ gene probes were carried out. So as to specifically detect the $m c y$ gene organization, the primers contained no sequences conserved among the NRPS and PKS genes. A set of primers to amplify the intergene region was designed from the sequences of $m c y$, umal, and dnaN of M. aeruginosa K-139 (Table 2, Fig. 1).

Expected PCR-amplified fragments were obtained from all toxic strains and 3 non-toxic strains, namely $M$. aeruginosa $\mathrm{K}-81$, S-78, and TC (Table 3). On the other hand, no desired PCR-fragments were detected in non-toxic strains, $M$. aeruginosa B-19, NIES44, NIES87, and NIES98, $M$. wesenbergii NIES112, and Microcystis MB (Table 3). 
Table 3. Summary of the amplification of non-coding regions involved in the microcystin synthetase gene cluster and other genes and the results of Southern hybridization of Microcystis DNA with the umal gene probe

\begin{tabular}{|c|c|c|c|c|c|c|c|c|c|c|c|}
\hline \multirow{2}{*}{ Strain } & \multicolumn{9}{|c|}{ PCR product name ${ }^{a}$} & \multirow{2}{*}{$\begin{array}{l}\text { umal } \\
\text { probe }\end{array}$} & \multirow{2}{*}{ Types } \\
\hline & N.J & I.J & H.I & G.H & A.D & B.C & C.U & N.U & X.U & & \\
\hline \multicolumn{12}{|l|}{ Microcystis spp. } \\
\hline M. aeruginosa NIES44 & - & - & - & - & - & - & - & - & - & + & (H) \\
\hline M. aeruginosa NIES89 & + & + & + & + & + & + & + & $\mathrm{nt}$ & $\mathrm{nt}$ & $\mathrm{nt}$ & (A) \\
\hline M. aeruginosa NIES90 & + & + & + & + & $+^{c}$ & + & + & $\mathrm{nt}$ & $\mathrm{nt}$ & $\mathrm{nt}$ & (C) \\
\hline M. aeruginosa NIES87 & - & - & - & - & - & - & - & - & + & + & (G) \\
\hline M. aeruginosa NIES98 & - & - & - & - & - & - & - & - & + & + & (G) \\
\hline M. aeruginosa NIES298 & + & + & + & + & + & + & + & $\mathrm{nt}$ & $\mathrm{nt}$ & $\mathrm{nt}$ & (A) \\
\hline M. aeruginosa K-81 & + & + & + & + & + & + & + & $\mathrm{nt}$ & $\mathrm{nt}$ & + & (A) \\
\hline M. aeruginosa $\mathrm{K}-139$ & + & + & + & + & + & + & + & $\mathrm{nt}$ & $\mathrm{nt}$ & + & (A) \\
\hline M. aeruginosa $\mathrm{B}-19$ & nt & - & - & - & - & - & $\mathrm{nt}$ & + & $\mathrm{nt}$ & + & $(\mathrm{F})$ \\
\hline M. aeruginosa $\mathrm{B}-35$ & + & + & + & + & + & + & + & $\mathrm{nt}$ & $\mathrm{nt}$ & $\mathrm{nt}$ & (A) \\
\hline M. aeruginosa $\mathrm{B}-47$ & $t^{d}$ & + & + & + & $+^{b}$ & + & + & $\mathrm{nt}$ & $\mathrm{nt}$ & $\mathrm{nt}$ & (B) \\
\hline M. aeruginosa S-77 & + & + & + & + & + & + & + & $\mathrm{nt}$ & $\mathrm{nt}$ & $\mathrm{nt}$ & (A) \\
\hline M. aeruginosa $\mathrm{S}-78$ & + & + & + & + & + & + & + & $\mathrm{nt}$ & $\mathrm{nt}$ & $\mathrm{nt}$ & (A) \\
\hline M. aeruginosa $\mathrm{TC}$ & + & + & + & + & + & + & + & $\mathrm{nt}$ & $\mathrm{nt}$ & $\mathrm{nt}$ & (A) \\
\hline M. viridis NIES103 & $+^{e}$ & + & + & + & + & + & + & - & - & nt & (E) \\
\hline M. viridis NIES102 & $t^{e}$ & + & + & + & + & + & + & - & - & nt & (E) \\
\hline M. viridis $\mathrm{S}-70$ & + & + & + & + & + & + & + & $\mathrm{nt}$ & $\mathrm{nt}$ & $\mathrm{nt}$ & (D) \\
\hline M. wesenbergii NIES107 & + & + & + & + & $+^{c}$ & + & + & - & $\mathrm{nt}$ & $\mathrm{nt}$ & (C) \\
\hline M. wesenbergii NIES112 & - & - & - & - & - & - & - & - & - & + & $(\mathrm{H})$ \\
\hline Microcystis $\mathrm{MB}$ & - & - & - & - & - & - & - & - & + & + & (G) \\
\hline Microcystis MG & + & + & + & + & + & + & + & - & - & + & (A) \\
\hline
\end{tabular}

${ }^{a}$ N.J, dnaN-mcyJ; I.J, mcyI-J; H.I, $m c y H-I$; G.H, $m c y G-H$; A.D, $m c y A-D$; B.C, $m c y B-C$; C.U, mcyC-umal; N.U, dnaN-umal; X.U, hypX-umal. ${ }^{b}$ A 195-bp fragment is inserted. ${ }^{c}$ A 175 -bp fragment is inserted. ${ }^{d}$ The $\operatorname{trp} 1$ gene is inserted. ${ }^{e}$ The trp 2 gene is inserted. ${ }^{f}$ Types indicate the gene organization of Figure 1. +, Amplified the expectant fragment; -, No expectant fragment; nt, not tested.

Sequence analysis revealed an extremely high level of homology among the PCR products: mcyI-J (98.1-100\% identity), mcyH-I (96.9-100\%), mcyG-H (94.7-100\%), mcyB-C (98.4-100\%), and mcyC-umal (95.2-100\%). Notably, between M. viridis NIES102 and NIES103, these amplicons were identical except for the mcyA-D products $(99.9 \%)$. Based on the sequence alignment of the mcyA-D products, $91.7-99.9 \%$ identity existed except for $M$. aeruginosa B-47 and NIES90, and M. wesenbergii NIES107 (Fig. $1 \mathrm{~B}$ and $1 \mathrm{C}$ ). Regarding the sequence of the mcyA-D amplicon of M. aeruginosa B-47, a 195-bp insert, which flanked the (CTAATTA) sequence, was observed between the putative promoter sequence of $m c y A$ and $m c y D$ as compared with strain K-139 (Table 3). This insert was identified with a miniature insertion element in a Microcystis strain (accession number, DQ022743). Moreover, in the case of $M$. aeruginosa NIES90 and $M$. wesenbergii NIES107, the mcyA-D sequence was identical and a 175-bp insert was observed as compared with M. aeruginosa K-139 between the translational start codon and the putative SD sequence (AGGGAAAAAG) of mcyA (Table 3). This 175-bp sequence showed no significant homology to any previously reported genes in the GenBank database. Non-coding nucleotide sequences of mcyH-I, mcyB-C, and mcyC-umal completely matched between M. aeruginosa NIES90 and M. wesenbergii NIES107 as well and the PCR amplicons of dnaN-mcyJ, mcyJ-I, and mcyG-H were 99.4, 99.5, and $98.8 \%$ identical, respectively.

\section{Identification of transposase genes between the dnaN and mcyJ genes}

Approximately 700-bp dnaN-mcyJ products, which included a 564-bp non-coding region, from $m c y$-positive $\left(m c y^{+}\right)$strains retaining the $m c y$ gene cluster, shared identity $(92.0-100 \%)$ with each other except for M. aeruginosa B47 and K-81, and M. viridis S-70, NIES102, and NIES103. 
(A)

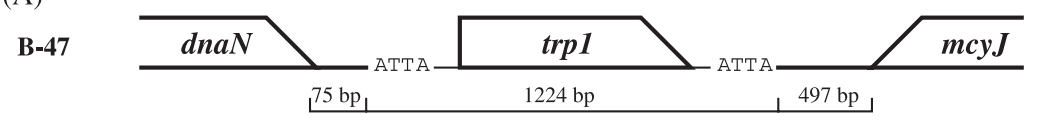

(B)

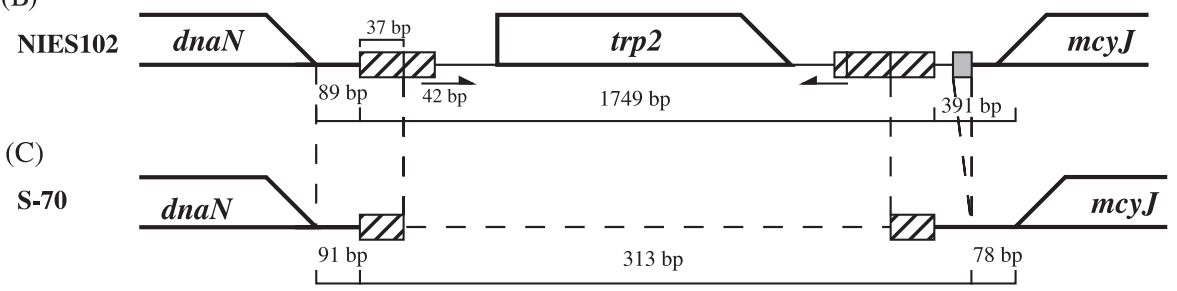

(D)

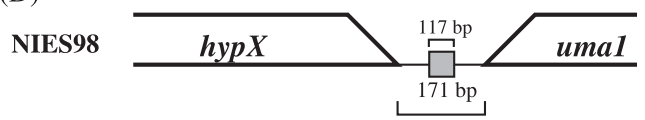

Fig. 2. Gene structure of inserted sequence in the $m c y$ gene cluster. (A) M. aeruginosa B-47, trp1, putative transposase of cyanobacteria; (B) M. viridis NISE102, trp2, Tn5-like transposase of bacteriophage WO; (C) M. viridis S-70; (D) M. aeruginosa NISE98. The rectangular box and arrows indicate the 37-bp repeated sequence and the inverted sequences, respectively. The black squared box represents a region of the highly homologous sequence. Each sequence shows the number of nucleotide base pairs under the gene structure.

Clearly, the dnaN-mcyJ products from M. aeruginosa K-81 had an extremely low level of similarity $(67.1-86.7 \%)$ in the non-coding sequence with those of other $m c y^{+} M$. aeruginosa strains. M. aeruginosa B-47, and M. viridis NIES 102 and NIES103 retained an open reading frame within the conserved non-coding region between mcyJ and dnaN as described below. The nucleotide sequence from $M$. aeruginosa B-47 showed an orf (855-bp), which exhibits homology (54.0\% identity) to the transposase of the cyanobacterium Calothrix sp. PCC 7601 (accession number, X60384) ${ }^{11)}$, between $d n a N$ and $m c y J$ (Fig. 1B and 2A). A direct repeat [ATTA] was found flanking trp1. Except for M. aeruginosa $\mathrm{K}-81$ and $\mathrm{B}-47$, and $M$. viridis NIES102, NIES103, and S-70, the nucleotide sequence alignment revealed an extremely high level of similarity with the dnaN-mcyJ amplicon sequence of $M$. aeruginosa K-139 $(98.0 \%)$.

In the case of $M$. viridis NIES102 and NIES103, an orf (1425-bp) was found between $d n a N$ and $m c y J$ (Fig. 1E) and, characterized as the transposase of bacteriophage WO (accession number, AB036665), exhibits similarity to the Tn5 transposase. The orf, designated trp2, shows no similarity to trp1 from M. aeruginosa B-47. Notably, four direct repeat sequences (37-bp, TCGATCCCCCCTTAATCCCCCCTTGATAAGGGGGGTG) were observed in the flanking region of trp2. One and two complete direct repeats were located upstream and downstream of trp2, respectively and another direct repeat was divided by $\operatorname{trp} 2$. An inverted repeat sequence (42-bp CCCCCCTTGATAA-
GCTATCCATTAGTCGGATCTTTCTTAACCA) flanked the trp2 gene (Fig. 2B). Interestingly, downstream of $m c y J$ of M. viridis NIES102, a 117-bp sequence with remarkable similarity to the non-coding region of umal-hypX of the $m c y$-negative $\left(m c y^{-}\right)$strain $M$. aeruginosa NIES98 was observed (Fig. 2B and D). Furthermore, the dnaN-mcyJ amplicon from $M$. viridis S-70 showed a 313-bp insert, which is identical to the flanking regions of trp 2 in $M$. viridis NIES102. This insert included two complete 37-bp direct repeats (Fig. 2C).

\section{Analysis of the mcy-negative (mcy $\left.{ }^{-}\right)$Microcystis strains}

In order to determine the umal downstream region of the mcy Microcystis strains, shotgun cloning using the umal probe was performed. An orf was identified 171-bp downstream of umal in a reversed orientation (Fig. $1 \mathrm{G}$ and 2D) in strain NIES98. This orf shows similarity (26.7\%) to a hypothetical 29.6-kDa lipoprotein in the DnaQ-GMHA intergenic reign precursor of $E$. coli $\mathrm{K}-12$, and is designated hypX. A part (117-bp) of this non-coding region in $M$. aeruginosa NIES98 was consistent with the non-coding region downstream of $m c y J$ in $M$. viridis NIES102 as described above. PCR amplification using primers 3'-hypX and 3'-umal showed that the genetic organization is the same among $M$. aeruginosa NIES87 and NIES98, and Microcystis MB. In M. aeruginosa NIES44 and M. wesenbergii NIES112, no PCR-amplified products were obtained using 3'-hypX and 3'-uma1. Additionally, to confirm whether the hypX gene exists on the chromosomal DNA of 


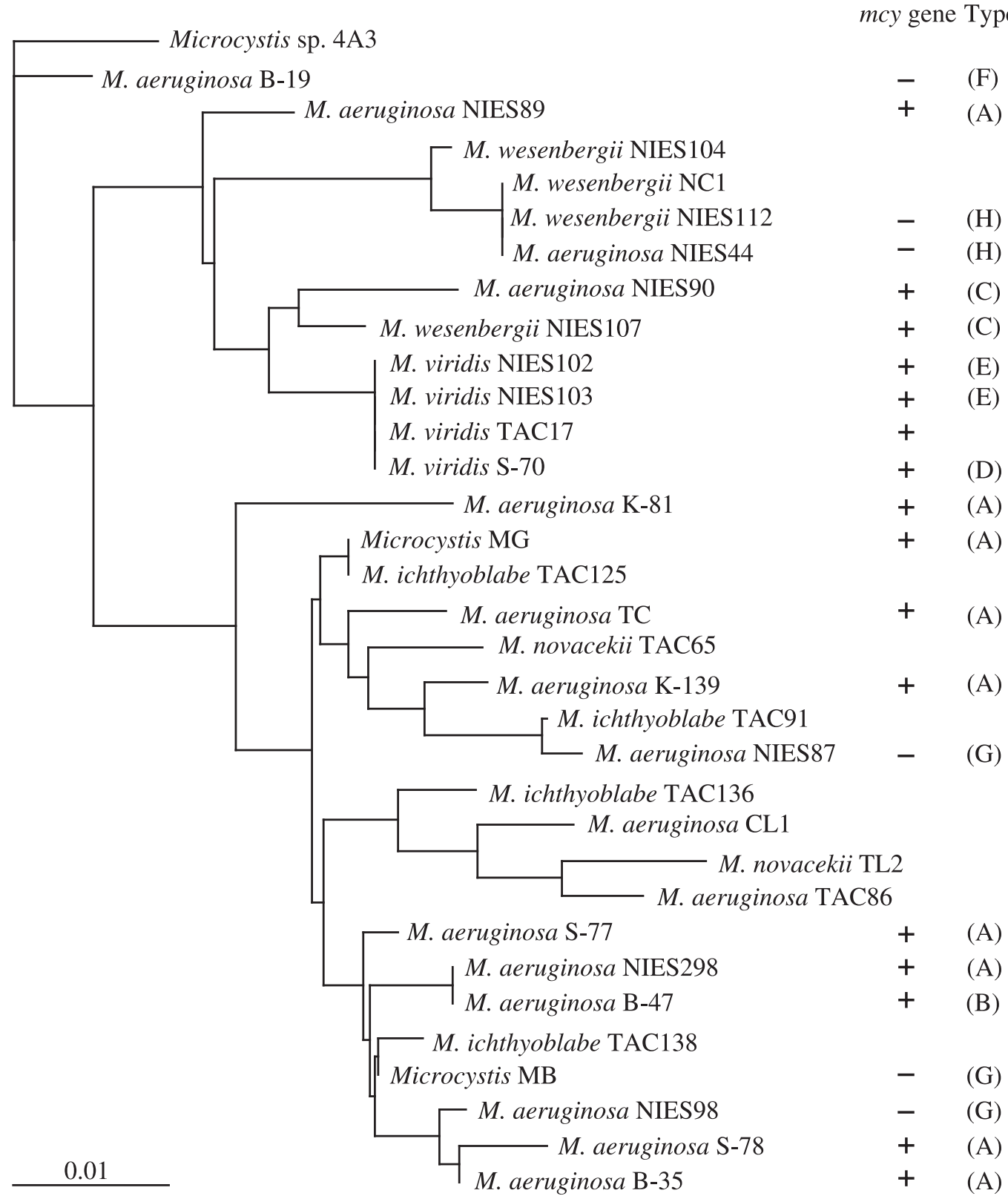

Fig. 3. Phylogenetic tree of the apparent evolutionary distances of the 16S-23S ITS sequence and the relationship of microcystin production with the $m c y$ gene cluster. The method of NJ (neighbor-joining) was carried out using the package CLUSTAL W. The seed number for the random number generator and numbers of bootstrap trials were set at 111 and 1000, respectively. Microcystin-producing strains and non-producing strains are listed in Table 2. Type indicated the structural feature in Fig. 1. Accession numbers of 16S-23S ITS were: Microcystis sp. 4A3, AB015357; M. aeruginosa TAC86, AB015363; CL1, AB015381; M. ichthyoblabe TAC91, AB015367; TAC125, AB015368; TAC136, AB015369; TAC138, AB015370; M. novacekii TAC65, AB015375; TL2, AB015380; M. viridis TAC17, AB015398; M. wesenbergii NIES104, AB015387; NIES112 (TAC52), AB015390; NC1, AB015393.

Microcystis, a PCR analysis was performed using another specific primer set for hypX. This investigation showed that no hypX was present in M. aeruginosa K-139 and NIES44, M. viridis NIES102 and NIES103, and M. wesenbergii NIES112. Therefore, these results suggested that the genetic organization downstream of umal in $M$. aeruginosa NIES44 and $M$. wesenbergii NIES112 was different from that in other $m c y^{-}$Microcystis strains. 


\section{Phylogenetic relationships based on 16S-23S ITS}

The primers utilized in this study enabled sequencing of both strands of 16S-23S ITS. The PCR amplification products (approximately 600-bp) of 22 Microcystis strains shown in Table 1 were sequenced. The amplified fragment included $74 \mathrm{bp}$ of the gene for tRNA-Ile. The nucleotide sequence of 16S-23S ITS from Microcystis TAC, TL, and NC1 strains, has been deposited in the Genome Sequence Database. Phylogenetic trees, constructed based on the NJ method using CLUSTAL W ${ }^{34)}$, are shown in Figure 3. Microcystis sp. 4A3 was used as an out-group sequence as a reference to Otsuka et al. ${ }^{21}$. Except for the $m c y^{-}$strain of $M$. aeruginosa B-19, Microcystis strains were roughly dividable into two groups; the $M$. viridis $-M$. wesenbergii group and the M. aeruginosa group (Fig. 3). The $m c y^{-}$strains, $M$. aeruginosa NIES87 and NIES98, M. wesenbergii NIES112, and Microcystis MB, were broadly dispersed to each branch in the M. aeruginosa group.

\section{Discussion}

Based on information on the mcy gene cluster, a molecular genetic approach was used to correlate the presence of the $m c y$ gene cluster with microcystin production among the genus Microcystis. Genetic analyses using the mcy-gene probes showed that some non-toxic Microcystis strains have retained the $m c y$ genes ${ }^{17,18)}$. We presumed that non-producers of microcystin developed as a result of a mutation or the repression of gene expression, or else toxin levels were below detection limits. Therefore, to reveal the mcy gene organization among the $m c y^{+}$and $m c y^{-}$Microcystis strains, we provided primer sets amplifying the non-coding region of the $m c y$ gene cluster. Recently, microcystin-producers and non-producers among Planktothrix strains were analyzed to develop a basis for the reliable detection of microcystin-producers using the eight regions of the $m c y$ gene cluster with PCR-amplification ${ }^{12}$. It was concluded that $m c y$ genes do not occur exclusively in microcystin-producing Planktothrix and that the mcy-genes in microcystin-producers can be highly variable. In the present study, our molecular genetic approach showed a highly conserved $m c y$ cluster using non-coding sequence alignments. Our approach will be applicable to the ecological detection of domesticated toxicogenic Microcystis strains.

The classification of Microcystis species is based on morphological features observed microscopically, such as cell size, cell arrangement in colonies, the existence of gas vesicles, and characteristics of the mucilage of colonies. It has been reported that a phylogenetic analysis of toxic and nontoxic Microcystis strains based on 16S rDNA was useful for determining the relation to taxonomy among closely related species and strains ${ }^{6,14}$. Neilan et al. studied the production of microcystin based only on the PCR amplification of one module, which activates L-amino acids, within the $m c y B$ gene among cyanobacteria ${ }^{15}$. This report described a method for the determination of potential microcystin-producing cyanobacteria. Tillett et al. have reported that the NMT region of $m c y A$, which was responsible for the $N$ methylation of amino acids, was used to separate toxic from non-toxic groups in Microcystis ${ }^{36}$. However, we have confirmed that some non-microcystin-producing M. aeruginosa strains possessed this module and other modules as well ${ }^{17,18)}$. To characterize and determine the classified domestic $m c y^{+}$strains and $m c y^{-}$strains, phylogenetic relationships based on 16S-23S ITS were determined based on the NJ method (Fig. 3). Our results indicated that the phylogenetic relationship of genus Microcystis strains do not correspond to the possession of $m c y$. Therefore, the possibility of toxicity in each strain should be verified by investigation of the mcy gene organization regardless of the phylogenetic relationship.

The process of horizontal gene transfer led to the formation of the genomic structure in the bacterium. Though there is a possibility that the mcy gene set was propagated by plasmids in the Microcystis strains, analyses of plasmids from toxic and non-toxic strains of Microcystis do not support the hypothesis of propagation ${ }^{28}$. Since the restriction and modification barrier of Microcystis is significantly strong $^{32)}$, transformation for propagation would be interfered with among the genus Microcystis. Analyzing a number of Microcystis strains in terms of their genetic organization would throw light on the difficult problem of how the $m c y$ gene cluster was acquired or lost. In this study, we confirmed the organization of the downstream of dnaN among microcystin-producers of Microcystis. Transposase gene (uma4) homologs located nearby the $m c y$ gene cluster have been reported ${ }^{13)}$. Although we found two kinds of transposase genes between dnaN and mcyJ, trp1, and trp2 did not correspond to the uma4 gene. According to these results, it seemed that downstream of dnaN often was selected as a preferable point for gene recombination. We presumed that a transferable transposase could occur through gene recombination of $m c y$. We have no evidence of gene transfer accompanying the $m c y$ gene cluster. Moreover, a database search of the Kazusa DNA Research Laboratory, revealed that Anabaena sp. PCC 7120 and Synechocystis PCC 6803 retained dnaN and umal homologs as 
well. However, no NRPS/PKS gene related with $m c y$ was found. Tillett et al. reported that umal was located downstream of $m c y C$ in toxic Microcystis strains and was detected in non-toxic strains ${ }^{36}$. To examine the vestige of $m c y$, we focused on the umal gene observed downstream of $m c y C$. In the $m c y^{-}$strains $M$. aeruginosa NIES87 and NIES98, and Microcystis MB, we identified the hypX gene as linked to umal, while umal was located beside $d n a N$ in $M$. aeruginosa B-19. Interestingly, part of the nucleotide sequence in $m c y J$ downstream of $M$. viridis NIES102 corresponded to part of the sequence between hypX and umal in the $m c y^{-}$strains (Fig. 2B and 2D). Considering the high degree of conservation of the mcy gene cluster and the results of the nucleotide sequence analyses of the region downstream of umal, even if the mcy gene cluster was inserted or lost in ancient cyanobacteria, some gene recombination occurred in this downstream region. In the case of $m c y^{-}$strains other than $M$. aeruginosa B-19, gene recombination occurred near the non-cording region between hyp $X$ and umal after the $m c y$ gene cluster was lost. Therefore, we propose that types $\mathrm{G}$ and $\mathrm{H}$ in Figure 1 involved several gene recombination events during evolution.

Consequently, by our molecular genetic approach we demonstrated that the organization of the mcy gene cluster with an adjacent dnaN was completely conserved among the domestic genus Microcystis. Considering the environmental problem of toxic cyanobacteria, profiling of the mcy gene cluster is important for knowledge of the microcystin synthetase gene and useful for the detection of $m c y$ from environmental field samples of Microcystis species.

\section{Acknowledgements}

We thank Dr. A. Kaplan for providing access to private culture collections. This research was supported by Scientific Research from the Ministry of Education, Science, Sports and Culture of Japan.

\section{References}

1) Carmichael, W.W. 1994. The toxins of cyanobacteria. Sci. Am. 270:78-86.

2) Christiansen, G., J. Fastner, M. Erhard, T. Börner, and E. Dittmann. 2003. Microcystin biosynthesis in Planktothrix: Genes, evolution, and manipulation. J. Bacteriol. 185:564-572.

3) Harada, K., K. Ogawa, K. Matsuura, H. Nagai, H. Murata, M. Suzuki, Y. Itezono, N. Nakayama, M. Shirai, and M. Nakano. 1991. Isolation of two toxic heptapeptide microcystins from an axenic strain of Microcystis aeruginosa K-139. Toxicon 29:479489.

4) Harada, K.-I., T. Nakano, K. Fujii, and M. Shirai. 2004. Compre- hensive analysis system using liquid chromatography-mass spectrometry for the biosynthetic study of peptides produced by cyanobacteria. J. Chromatogr. A, 1033:107-113.

5) Jochimsen, E.M., W.W. Carmichael, J.S. An, D.M. Cardo, S.T. Cookson, C.E. Holmes, M.B. Antunes, D.A.M. Filho, T.M. Lyra, V.S. Barreto, S.M. Azevedo, and W.R. Jarvis. 1998. Liver failure and death after exposure to microcystins at a hemodialysis center in Brazil. N. Engl. J. Med. 338:873-878.

6) Lu, W., E.H. Evans, S.M. McColl, and V.A. Saunders. 1997. Identification of cyanobacteria by polymorphisms of PCR-amplified ribosomal DNA spacer region. FEMS Microbiol. Lett. 153:141-149.

7) Lyra, C., S. Suomalainen, M. Gugger, C. Vezie, P. Sundman, L. Paulin, and K. Sivonen. 2001. Molecular characterization of planktic cyanobacteria of Anabaena, Aphanizomenon, Microcystis, and Planktothrix genera. Int. J. Syst. Evol. Microbiol. 51:513526.

8) MacKintosh, C., K.A. Beattie, S. Klumpp, P. Cohen, and G.A. Codd. 1990. Cyanobacterial microcystin-LR is a potent and specific inhibitor of protein phosphatases 1 and $2 \mathrm{~A}$ from both mammals and higher plants. FEBS Lett. 264:187-192.

9) Marahiel, M.A. 1997. Protein templates for the biosynthesis of peptide antibiotics. Chem. Biol. 4:561-567.

10) Martin, C., L. Oberer, T. Ino, W.A. König, M. Busch, and J. Weckesser. 1993. Cyanopeptolins, new depsipeptides from the cyanobacterium Microcystis sp. PCC7806. J. Antibiot. 46:1550 1556.

11) Mazel, D., C. Bernard, R. Schwarz, A.M. Castets, J. Houmard, and N. Tandeau de Marsac. 1991. Characterization of two insertion sequences, IS701 and IS702, from the cyanobacterium Calothrix species PCC 7601. Mol. Microbiol. 5:2165-2170.

12) Mbedi, S., M. Welker, J. Fastner, and C. Wiedner. 2005. Variability of the microcystin synthetase gene cluster in the genus Planktothrix (Oscillatoriales, Cyanobacteria). FEMS Microbiol. Lett. 245:299-306.

13) Mikalsen, B., G. Boison, O.M. Skulberg, J. Fastner, W. Davies, T.M. Gabrielsen, K. Rudi, and K.S. Jakobsen. 2003. Natural variation in the microcystin synthetase operon $m c y A B C$ and impact on microcystin production in Microcystis strains. J. Bacteriol. 185:2774-2785.

14) Neilan, B.A., D. Jacobs, T. Del Dot, L.L. Blackall, P.R. Hawkins, P.T. Cox, and A.E. Goodman. 1997. rRNA sequences and evolutionary relationships among toxic and nontoxic cyanobacteria of the genus Microcystis. Int. J. Syst. Bacteriol. 47:693-697.

15) Neilan, B.A., E. Dittmann, L. Rouhiainen, R.A. Bass, V. Schaub, K. Sivonen, and T. Börner. 1999. Nonribosomal peptide synthesis and toxigenicity of cyanobacteria. J. Bacteriol. 181:4089-4097.

16) Nishiwaki-Matsushima, R., T. Ohta, S. Nishiwaki, M. Suganuma, K. Kohyama, T. Ishikawa, W.W. Carmaichael, and H. Fujiki. 1992. Liver tumor promotion by the cyanobacterial cyclic peptide toxin microcystin-LR. J. Cancer Res. Clin. Oncol. 118:420-424.

17) Nishizawa, T., M. Asayama, K. Fujii, K.-I. Harada, and M. Shirai. 1999. Genetic analysis of the peptide synthetase genes for a cyclic heptapeptide microcystin in Microcystis spp. J. Biochem. 126:520-529.

18) Nishizawa, T., A. Ueda, M. Asayama, K. Fujii, K.-I. Harada, K. Ochi, and M. Shirai. 2000. Polyketide synthase gene coupled to the peptide synthetase module involved in the biosynthesis of the cyclic heptapeptide microcystin. J. Biochem. 127:779-789.

19) Nishizawa, T., M. Asayama, and M. Shirai. 2001. Cyclic hep- 
tapeptide microcystin biosynthesis requires the glutamate racemase gene. Microbiology 147:1235-1241.

20) Ohtake, A., M. Shirai, T. Aida, N. Mori, K.-I. Harada, K. Matsuura, M. Suzuki, and M. Nakano. 1989. Toxicity of Microcystis species isolated from natural blooms and purification of the toxin. Appl. Environ. Microbiol. 55:3202-3207.

21) Otsuka, S., S. Suda, R. Li, M. Watanabe, H. Oyaizu, S. Matsumoto, and M.M. Watanabe. 1999. Phylogenetic relationships between toxic and non-toxic strains of the genus Microcystis based on $16 \mathrm{~S}$ to $23 \mathrm{~S}$ internal transcribed spacer sequence. FEMS Microbiol. Lett. 172:15-21.

22) Pearson, L.A., M. Hisbergues, T. Börner, E. Dittmann, and B.A. Neilan. 2004. Inactivation of an $\mathrm{ABC}$ transporter gene, $m c y H$, results in loss of microcystin production in the cyanobacterium Microcystis aeruginosa PCC 7806. Appl. Environ. Microbiol. 70:6370-6378.

23) Pearson, L.A., K.D. Barrow, and B.A. Neilan. 2007. Characterization of the 2-hydroxy-acid dehydrogenase McyI, encoded within the microcystin biosynthesis gene cluster of Microcystis aeruginosa PCC7806. J. Biol. Chem. 282:4681-4692.

24) Rantala, A., D.P. Fewer, M. Hisbergues, L. Rouhiainen, J. Vaitomaa, T. Börner, and K. Sivonen. 2004. Phylogenetic evidence for the early evolution of microcystin synthesis. Proc. Natl. Acad. Sci. USA 101:568-573.

25) Rouhiainen, L., T. Vakkilainen, B.L. Siemer, W. Buikema, R. Haselkorn, and K. Sivonen. 2004. Genes coding for hepatotoxic heptapeptides (microcystins) in the cyanobacterium Anabaena strain 90. Appl. Environ. Microbiol. 70:686-692.

26) Sakamoto, T., M. Shirai, M. Asayama, T. Aida, A. Sato, K. Tanaka, H. Takahashi, and M. Nakano. 1993. Characteristics of DNA and multiple rpoD homologs of Microcystis (Synechocystis) strain. Int. J. Syst. Bacteriol. 43:844-847.

27) Sambrook, J., E.F. Fritsch, and M. Maniatis. 1989. Molecular cloning; a laboratory manual, 2nd Ed. Cold Spring Harbor Laboratory Press, Cold Spring Harbor, N.Y.

28) Schwabe, W., A. Weihe, T. Börner, M. Henning, and J.-G. Kohl. 1988. Plasmids in toxic and nontoxic strains of the cyanobacterium Microcystis aeruginosa. Curr. Microbiol. 17:133-137.

29) Shirai, M., K. Matsumaru, A. Ohtake, Y. Takamura, T. Aida, and M. Nakano. 1989. Development of a solid medium for growth and isolation of axenic Microcystis strains (cyanobacteria). Appl. Environ. Microbiol. 55:2569-2571.

30) Shirai, M., A. Ohtake, T. Sano, S. Matsumoto, T. Sakamoto, A.
Sato, T. Aida, K.-I. Harada, T. Shimada, M. Suzuki, and M. Nakano. 1991. Toxicity and toxins of natural blooms and isolated of Microcystis spp. (Cyanobacteria) and improved procedure for purification of cultures. Appl. Environ. Microbiol. 57:12411245.

31) Sielaff, H., E. Dittmann, N. Tandeau de Marsac, C. Bouchier, H. von Döhren, T. Börner, and T. Schwecke. 2003. The $m c y F$ gene of the microcystin biosynthetic gene cluster from Microcystis aeruginosa encodes and aspartate racemase. Biochem. J. 373:909-916.

32) Takahashi, I., D. Hayano, M. Asayama, F. Masahiro, M. Watahiki, and M. Shirai. 1996. Restriction barrier composed of an extracellular nuclease and restriction endonuclease in the unicellular cyanobacterium Microcystis sp. FEMS Microbiol. Lett. 145:107-111.

33) Tanabe, Y., K. Kaya, and M.M. Watanabe. 2004. Evidence for recombination in the microcystin synthetase ( $m c y$ ) genes of toxic cyanobacteria Microcystis spp. J. Mol. Evol. 58:633-641.

34) Thompson, J.D., D.G. Higgins, and T.J. Gibson. 1994. CLUSTAL W: improving the sensitivity of progressive multiple sequence alignment through sequence weighting, position specific gap penalties and weight matrix choice. Nucleic Acids Res. 22:4673-4680.

35) Tillett, D., E. Dittmann, M. Erhard, H. von Döhren, T. Börner, and B.A. Neilan. 2000. Structural organization of microcystin biosynthesis in Microcystis aeruginosa PCC7806: an integrated peptide-polyketide synthetase system. Chem. Biol. 7:753-764.

36) Tillett, D., D.L. Parker, and B.A. Neilan. 2001. Detection of toxigenicity by a probe for the microcystin synthetase a gene $(m c y A)$ of the cyanobacterial genus Microcystis: Comparison of toxicities with 16S rRNA and phycocyanin operon (phycocyanin intergenic spacer) phylogenies. Appl. Environ. Microbiol. 67:2810-2818.

37) Vardi, A., D. Schatz, K. Beeri, U. Motro, A. Sukenik, A. Levine, and A. Kaplan. 2002. Dinoflagellate-cyanobacterium communication may determine the composition of phytoplankton assemblage in a mesotrophic lake. Curr. Biol. 12:1767-1772.

38) Watanabe, M.F. 1996. Production of microcystins, p. 35-56. In M.F. Watanabe, K.-I. Harada, W.W. Carmichael, and H. Fujiki (ed.), Toxic Microcystis. CRC Press. Boca Raton, FL, USA.

39) Yoshida, T., Y. Yuki, S. Lei, H. Chinen, M. Yoshida, R. Kondo, and S. Hiroishi. 2003. Quantitative detection of toxic strains of the cyanobacterial genus Microcystis by competitive PCR. Microbes Environ. 18:16-23. 